\title{
ASSESSING THE INFLUENCE OF THE PRESENCE OF HEAVY METALS ADSORBED ON ACTIVATED CARBON ON THE EFFICIENCY OF DEGRADATION OF PHENOL USING SELECTED OXIDIZING AGENTS
}

\author{
OCENA WPŁYWU OBECNOŚCI METALI CIĘ̇̇KICH \\ ZAADSORBOWANYCH NA WECGLU AKTYWNYM \\ NA SKUTECZNOŚĆ DEGRADACJI FENOLU \\ WYBRANYMI CZYNNIKAMI UTLENIAJĄCYMI
}

\begin{abstract}
Removing organic substances from wastewater is a complex problem. Different methods are used for this purpose. Recently, much attention has been given to the application of sorption and advanced oxidation processes (AOPs), which contribute also to the regeneration of activated carbon. The analysis presented in this paper focused on determining the influence of $\mathrm{Cu}$ (II) and $\mathrm{Fe}$ (II) ions adsorbed on activated carbon on the efficiency of oxidation of phenol by means of $\mathrm{H}_{2} \mathrm{O}_{2}$, Fenton's reagent $\mathrm{Fe}^{2+} / \mathrm{H}_{2} \mathrm{O}_{2}$ and 1:1 $\mathrm{HNO}_{3}$ solution exposed to $2450 \mathrm{MHz}$ microwaves, and, accordingly, the influence of $\mathrm{Cu}$ (II) and $\mathrm{Fe}$ (II) ions on the sorptive capacity of regenerated activated carbons. The results show that the chemical regeneration of activated carbon using AOPs resulted in partial oxidation of the adsorbed organic substance. The presence of $\mathrm{Cu}$ (II) or $\mathrm{Fe}$ (II) ions increased the regeneration efficiency. Using nitric acid to oxidize adsorbed phenol brought about a dramatic decline in the sorptive capacity of activated carbon with respect to this substance and an increase in the sorptive capacity of carbon with respect to metal ions. A serious drawback of this method, however, is that the oxidation of adsorbed phenol caused a significant loss of mass of activated carbon regardless of the oxidizing agent used.
\end{abstract}

Keywords: activated carbon, sorption, regeneration, oxidation, heavy metals

The removal of toxic organic substances from wastewater is a difficult and complex process. It involves applying various physical, chemical, electrochemical and biological methods. Wastewater arising from the activities of the chemical, petrochemical, coke and pharmaceutical industries is particularly difficult to treat because it contains aromatic organic compounds, including phenol and its derivatives. Today, more and more attention is being paid to the application of oxidation reaction, for instance Fenton's reaction, $\left(\mathrm{Fe}^{2+} / \mathrm{H}_{2} \mathrm{O}_{2}\right)$, to remove organic pollutants from industrial waste [1-3]. In Fenton's reaction, the oxidizing agent is the generated hydroxyl radicals, and the procedure is classified to be

\footnotetext{
${ }^{1}$ Faculty of Civil and Environmental Engineering, Kielce University of Technology, al. Tysiąclecia Państwa Polskiego 7, 25-314 Kielce, Poland, phone +48 413424 535, fax +48 413443784

* Corresponding author: ldabek@tu.kielce.pl
} 
an Advanced Oxidation Process (AOP) [1-8]. Oxidizing organic substances in aqueous solutions requires using large amounts of reagents and energy and disposing of wastewater containing oxidation by-products. A possible solution to the problem is to combine the processes of oxidation and sorption of organic compounds on activated carbon [1-8]. The sorbent introduced into the reaction system enables not only sorption of the pollutants present in the solution but also oxidation of by-products. As shown in the literature, eg $[1,3,5,8]$, activated carbon introduced into a hydrogen peroxide solution and $\mathrm{Fe}^{2+} / \mathrm{H}_{2} \mathrm{O}_{2}$, acts as a sorbent and a catalyst in the process of generation of hydroxyl radicals. Since the formation of hydroxyl radicals in Fenton's reaction is mainly due to the presence of $\mathrm{Fe}^{2+}$ or $\mathrm{Cu}^{2+}$ ions, a question arises whether these metals adsorbed on the surface of activated carbon affect the efficiency of oxidation of the adsorbed organic substances. The problem described here was illustrated by oxidation of phenol adsorbed on activated carbon.

\section{Methodology}

The study was conducted using commercially available activated carbon, Filtrasorb 300 (F-300).

\section{Sorption isotherms}

Sorption isotherms were determined for a system of $0.5 \mathrm{~g}$ of activated carbon, F-300, and $200 \mathrm{~cm}^{3}$ of solution containing $\mathrm{Cu}$ (II) and $\mathrm{Fe}(\mathrm{II})$ ions, with concentrations ranging from 1.5 to $40.0 \mathrm{mg} / \mathrm{dm}^{3}$, and phenol $(\mathrm{Ph})$, with concentrations ranging from 50 to $750 \mathrm{mg} / \mathrm{dm}^{3}$. The contact time required to achieve equilibrium was 3 hours. The isotherms of sorption of phenol (F-300/Ph) and metal ions from aqueous solutions were determined in the following order: activated carbon, F-300, with $\mathrm{Cu}$ (II) ions adsorbed as first and phenol adsorbed as second $(\mathrm{F}-300 / \mathrm{Cu} / \mathrm{Ph})$; activated carbon, F-300, with $\mathrm{Fe}(\mathrm{II})$ ions adsorbed as first and phenol adsorbed as second $(\mathrm{F}-300 / \mathrm{Fe} / \mathrm{Ph})$; activated carbon with phenol adsorbed as first and $\mathrm{Cu}(\mathrm{II})$ ions adsorbed as second $(\mathrm{F}-300 / \mathrm{Ph} / \mathrm{Cu})$; activated carbon, F-300, with phenol adsorbed as first and $\mathrm{Fe}(\mathrm{II})$ ions adsorbed as second $(\mathrm{F}-300 / \mathrm{Ph} / \mathrm{Fe})$; and activated carbon, F-300, with a mixture of metal ions and phenol $((\mathrm{F}-300 /(\mathrm{Cu}+\mathrm{Ph})$ or $\mathrm{F}-300 /(\mathrm{Fe}+\mathrm{Ph}))$.

\section{Concentration of metal ions in an aqueous solution}

The concentration of metal ions was established using a Spectroquant NOVA 60 spectrophotometer and performing MERCK Spectroquant tests.

\section{Concentration of phenol in an aqueous solution}

The concentration of phenol was measured using a Thermo Scientific Focus GC gas chromatograph equipped with an MS detector and a TRACE-TR-1MS GC column, operating at temperatures ranging from 40 to $260^{\circ} \mathrm{C}$.

An $X$-ray Diffraction (XRD) analysis of the catalysts was conducted using a Siemens D500 diffractometer $(\mathrm{CuK} \alpha$ radiation; $\lambda=0.154 \mathrm{~nm})$. 


\section{Regeneration of activated carbons by oxidation of adsorbed organic pollutants}

\section{Using hydrogen peroxide}

$5 \mathrm{~g}$ samples of activated carbon, F-300, saturated with phenol and metal ions were immersed in $200 \mathrm{~cm}^{3}$ of $\mathrm{H}_{2} \mathrm{O}_{2}$ solution with a concentration of $0.7 \mathrm{M} / \mathrm{dm}^{3}$ and a $\mathrm{pH}$ of 8.1 . The contents were shaken for $1 \mathrm{~h}$ at a temperature of $20 \pm 2^{\circ} \mathrm{C}$. Subsequently, the hydrogen peroxide solution was decanted, and the carbon was rinsed, once with $100 \mathrm{~cm}^{3}$ of diluted $\mathrm{H}_{2} \mathrm{SO}_{4}$ solution $(\mathrm{pH}=4)$ and four times with $100 \mathrm{~cm}^{3}$ of distilled water.

\section{Using Fenton's reaction}

$5 \mathrm{~g}$ samples of activated carbon, F-300, saturated with phenol and metal ions, were treated with $100 \mathrm{~cm}^{3}$ of distilled water. Then, $\mathrm{FeSO}_{4}$ and $\mathrm{H}_{2} \mathrm{O}_{2}$ solutions $(\mathrm{pH}=3 \div 4)$ were added simultaneously, maintaining the $\mathrm{Fe}^{2+} / \mathrm{H}_{2} \mathrm{O}_{2}$ ratio by weight of 1:5. The contents were mixed intensively for $1 \mathrm{~h}$. Then, the solution with Fenton's reagent was decanted and the carbon was rinsed once with $100 \mathrm{~cm}^{3}$ of diluted $\mathrm{NaOH}$ solution $(\mathrm{pH} \sim 8$ ) (in order to stop the oxidation reaction) and four times with $100 \mathrm{~cm}^{3}$ of distilled water.

\section{In the $\mathrm{HNO}_{3}$ environment in the presence of microwaves}

$5 \mathrm{~g}$ samples of activated carbon, F-300, saturated with phenol and metal ions was treated with 1:1 $\mathrm{HNO}_{3}$ solution ( $1 \mathrm{~g}$ of regenerated activated carbon per $10 \mathrm{~cm}^{3}$ of oxidizing solution) and heated for $5 \mathrm{~min}$ in a $2450 \mathrm{MHz}$ microwave field, using a UniClever Plazmatronika microwave mineralizer. The solution from over the carbon was decanted. The procedure was repeated three times. The regenerated activated carbon was rinsed with distilled water until neutral $\mathrm{pH}$ was achieved.

\section{Characteristics of activated carbons}

The porous structure of activated carbon was analyzed by performing low-temperature adsorption of nitrogen $(77 \mathrm{~K})$. The adsorption and desorption isotherm was determined with a Fisons Sorptomatic 1900 using the volumetric method. The total concentration of the acidic groups was established in a titration analysis with $0.01 \mathrm{M} \mathrm{HCl}$ solution, which requires titrating the surplus non-reacted $0.01 \mathrm{M} \mathrm{NaOH}$ used for treating the analyzed carbon samples.

\section{Discussion of results}

The influence of metals, ie $\mathrm{Cu}$ (II) and $\mathrm{Fe}(\mathrm{II})$, present on the surface of activated carbon on the effectiveness of degradation of adsorbed phenol was assessed by analyzing the physical and chemical properties and the sorptive capacity of the selected activated carbon, F-300. The analyzed processes were: the sorption of phenol $(\mathrm{Ph})$ on virgin activated carbon, F-300, ie F-300/Ph, the sorption of phenol on activated carbon, F-300, with $\mathrm{Fe}(\mathrm{II})$ and $\mathrm{Cu}(\mathrm{II})$ ions adsorbed as first, ie $\mathrm{F}-300 / \mathrm{Cu} / \mathrm{Ph}$ and $\mathrm{F}-300 / \mathrm{Fe} / \mathrm{Ph}$, respectively, the sorption of $\mathrm{Cu}(\mathrm{II})$ and $\mathrm{Fe}(\mathrm{II})$ ions on activated carbon with phenol adsorbed as first, ie F-300/Ph/Cu and F-300/Ph/Fe, respectively, and the simultaneous sorption of phenol and metal ions, ie $\mathrm{F}-300 /(\mathrm{Cu}+\mathrm{Ph})$ and $\mathrm{F}-300 /(\mathrm{Fe}+\mathrm{Ph})$. As shown in Table 1, activated carbon, F-300, commonly applied as a sorbent of organic and non-organic impurities, is characterized by a well-developed porous structure (a surface area of $965 \mathrm{~m}^{2} / \mathrm{g}$ and a pore volume of $0.57 \mathrm{~cm}^{3} / \mathrm{g}$ ) and moderate surface acidity of $0.57 \mathrm{mmol} / \mathrm{g}$. The sorptive capacity 
of virgin carbon, F-300, with respect to phenol and $\mathrm{Cu}(\mathrm{II})$ and $\mathrm{Fe}(\mathrm{II})$ ions was 180 , 12 and $5.5 \mathrm{mg} / \mathrm{g}$, respectively (Table 2). It was found that the presence of the $\mathrm{Cu}$ (II) ions adsorbed as first did not contribute to the lower sorption of phenol. The influence of the presence of $\mathrm{Fe}$ (II) ions was also very small. The results indicate that the metal ions were sorbed at active centres other than phenol, yet they participated in the process actively. They confirm the literature data [9-11], which suggest that the sorption of metals takes place on acidic oxygen groups at the carbon surface, whereas the sorption of phenol is attributable to the presence of basic functional groups. The presence of metals ensured high sorptive capacity of the activated carbon with respect to phenol as a result of the donor-acceptor interactions between metal and electrons $\pi$ of the aromatic rings, despite the fact that part of the surface area of the activated carbon was already non-active. On the other hand, the sorption of metal ions on activated carbon with phenol adsorbed as first was lower; for $\mathrm{Cu}$ (II) it was $8 \mathrm{mg} / \mathrm{g}$, while for $\mathrm{Fe}(\mathrm{II})$ it amounted to $5 \mathrm{mg} / \mathrm{g}$. This indicates that the particles of the adsorbed phenol cover the active centres capable of the sorption of metal ions because of their size or change the chemical character of the surface of the activated carbon. Sorption from the metal ion-phenol mixture, F-300/(Cu+Ph) and F-300/(Fe+Ph), was considerably lower. For $\mathrm{Fe}(\mathrm{II}), \mathrm{Cu}(\mathrm{II})$ and phenol, it was 6,4 and $110 \mathrm{mg} / \mathrm{g}$, respectively. This can be explained by the result of competition in the diffusive area as well as the occurrence of donor-acceptor interactions between phenol and metal ions in the solution.

Table 1

Characteristics of virgin activated carbon, F-300, and carbon exposed to oxidants

\begin{tabular}{|c|c|c|c|c|c|}
\hline $\begin{array}{c}\text { Symbol of carbon } \\
\text { sample }\end{array}$ & Oxidation conditions & $\begin{array}{c}\text { Surface area } \\
\mathbf{S} \\
{\left[\mathbf{m}^{\mathbf{2}} / \mathbf{g}\right]}\end{array}$ & $\begin{array}{c}\text { Pore volume } \\
\mathbf{V} \\
{\left[\mathbf{c m}^{\mathbf{3}} / \mathbf{g}\right]}\end{array}$ & $\begin{array}{c}\text { Surface } \\
\text { acidity } \\
{[\mathbf{m m o l} / \mathbf{g}]}\end{array}$ & $\begin{array}{c}\text { Loss } \\
\text { of mass } \\
{[\%]}\end{array}$ \\
\hline $\mathrm{F}-300$ & - & 965 & 0.57 & 0.57 & - \\
\hline $\mathrm{F}-300 / \mathrm{HNO}_{3}$ & $\begin{array}{c}\text { activated carbon/1:1HNO} / \mathrm{HNO}_{3} / \\
2450 \mathrm{MHz} / 80 \% / 5 \mathrm{~min}\end{array}$ & 850 & 0.72 & 2.2 & 25 \\
\hline $\mathrm{F}-300 / \mathrm{H}_{2} \mathrm{O}_{2}$ & $\begin{array}{c}\text { activated carbon } \mathrm{H}_{2} \mathrm{O}_{2} \\
\left(0.7 \mathrm{M} / \mathrm{dm}^{3}\right) / 60 \mathrm{~min}\end{array}$ & 960 & 0.68 & 1.6 & 12 \\
\hline $\mathrm{F}-300 / \mathrm{Fe}^{2+} / \mathrm{H}_{2} \mathrm{O}_{2}$ & $\mathrm{Fe}^{2+}: \mathrm{H}_{2} \mathrm{O}_{2} 1: 5 / 60 \mathrm{~min}$ & 910 & 0.70 & 1.8 & 22 \\
\hline
\end{tabular}

Sorptive capacity of virgin activated carbon, F-300, with respect to the selected metal ions and phenol from an aqueous solution depending on the sequence of the substances sorbed

\begin{tabular}{|c|c|c|}
\hline $\begin{array}{c}\text { Symbol of sample: } \\
\text { activated carbon F-300/first-sorbed component/ } \\
\text { second-sorbed component, or (sorption } \\
\text { from the mixture) }\end{array}$ & $\begin{array}{c}\text { Sorptive capacity } \\
\text { of carbon with respect to } \\
\text { a selected ion } \\
\text { [mg/g] }\end{array}$ & $\begin{array}{c}\text { Sorptive capacity } \\
\text { of carbon with } \\
\text { respect to phenol } \\
\text { [mg/g] }\end{array}$ \\
\hline $\mathrm{F}-300$ & - & 180 \\
\hline $\mathrm{F}-300 / \mathrm{Cu} / \mathrm{Ph}$ & 12.0 & 180 \\
\hline $\mathrm{F}-300 / \mathrm{Fe} / \mathrm{Ph}$ & 5.5 & 170 \\
\hline $\mathrm{F}-300 / \mathrm{Ph} / \mathrm{Cu}$ & 8.0 & 180 \\
\hline $\mathrm{F}-300 / \mathrm{Ph} / \mathrm{Fe}$ & 5.0 & 180 \\
\hline $\mathrm{F}-300 /(\mathrm{Cu}+\mathrm{Ph})$ & 4.0 & 110 \\
\hline $\mathrm{F}-300 /(\mathrm{Fe}+\mathrm{Ph})$ & 6.0 & 110 \\
\hline
\end{tabular}


The next stage of the analysis involved chemical regeneration of activated carbons saturated with phenol and metal ions using different oxidizing agents: $1: 1 \mathrm{HNO}_{3}$ solution exposed to microwaves; $\mathrm{H}_{2} \mathrm{O}_{2}$ solution with $\mathrm{pH}$ of 8.1 and $\mathrm{Fe}^{2+} / \mathrm{H}_{2} \mathrm{O}_{2}$ solution with $\mathrm{pH}$ of $3 \div 4$. The reaction conditions as well as the amount of oxidant introduced into the reaction environment were properly selected to ensure optimal, ie stoichiometric, oxidation.

The first task was to assess the influence of these oxidants on virgin activated carbon, F-300. As shown in Table 1, the oxidizing agents caused changes in the porous structure as well as chemical composition of the sorbent at the surface. The greatest changes were observed for nitric acid. When the $1: 1 \mathrm{HNO}_{3}$ solution reached its boiling point in the presence of microwaves, there was a considerable reduction in the specific surface from 965 to $850 \mathrm{~m}^{2} / \mathrm{g}$ with a simultaneous increase in the volume of pores, which indicates a reduction in the volume of micropores and a rise in the volume of mesopores. The changes in the porous structure were accompanied by changes in the chemical character of the surface, ie a considerable shift towards acidity. Hydrogen peroxide and Fenton's reagent were both responsible for a significant increase in the surface acidity after oxidation; the changes in the porous structure were negligent. However, the use of all the oxidants resulted in a significant loss of mass of the activated carbon reaching 25, 12 and $22 \%$ for $\mathrm{HNO}_{3}$, $\mathrm{H}_{2} \mathrm{O}_{2}$ and $\mathrm{Fe}^{2+} / \mathrm{H}_{2} \mathrm{O}_{2}$, respectively.

Using the same conditions for carbons saturated with phenol and metal ions, ie $\mathrm{Cu}(\mathrm{II})$ and $\mathrm{Fe}(\mathrm{II})$, resulted in the oxidation of the adsorbed organic substance. In the Fenton's reaction and in the nitric acid environment, the decomposition of phenol occurred at the boiling point. No such effect was observed for hydrogen peroxide. The oxidation of phenol adsorbed on the surface of activated carbon confirms that the presence of activated carbon contributed to the decomposition of hydrogen peroxide and the generation of hydroxyl radicals in the reaction environment. The efficiency of the decomposition of phenol increased in the presence of the adsorbed $\mathrm{Cu}$ (II) and $\mathrm{Fe}$ (II) ions, as suggested by the results of the secondary sorption in Table 2. The sorptive capacity of activated carbon saturated with phenol, F-300/Ph, after regeneration with hydrogen peroxide and Fenton's reagent was $100 \div 110 \mathrm{mg} / \mathrm{g}$. The sorptive capacity of carbon regenerated with these two agents with respect to $\mathrm{Cu}(\mathrm{II})$ and $\mathrm{Fe}(\mathrm{II})$ ions was 8 and $12 \mathrm{mg} / \mathrm{g}$, and 3 and $6 \mathrm{mg} / \mathrm{g}$, respectively. The values are comparable to those obtained for activated carbon, F-300, exposed to the same agents. The sorptive capacity of activated carbon, F-300, saturated with $\mathrm{Cu}$ (II) and $\mathrm{Fe}$ (II) ions and phenol after regeneration with hydrogen peroxide and Fenton's reagent amounted to $150 \mathrm{mg} / \mathrm{g}$, which was higher than the sorptive capacity of regenerated F-300/Ph carbon.

The experimental results are consistent with the literature data $[4,6]$, which suggest that the presence of metals adsorbed on activated carbon, ie both $\mathrm{Fe}(\mathrm{II})$ and $\mathrm{Cu}$ (II), causes an increase in the efficiency of decomposition of $\mathrm{H}_{2} \mathrm{O}_{2}$ and contributes to the generation of hydroxyl radicals as well as an increase in the concentration of acidic oxygen groups on the sorbent surface. The analysis shows that it was due to the relatively high sorptive capacity of the regenerated activated carbons with respect to metal ions. During the oxidation of adsorbed phenol, the concentration of metal ions on the carbon surface did not change, which indicates that their total concentration increased after the oxidation and the second sorption.

The efficiency of oxidation of the adsorbed phenol was higher in the presence of copper than in the presence of iron on the surface of activated carbon despite the fact that 
in both cases hydroxyl radicals were generated in accordance with the following equations $[1,6]$ :

$$
\begin{gathered}
\mathrm{Cu}(\mathrm{II})+\mathrm{H}_{2} \mathrm{O}_{2} \rightarrow \mathrm{Cu}(\mathrm{I})+\mathrm{HO}_{2}^{*}+\mathrm{H}^{+} \\
\mathrm{Cu}(\mathrm{I})+\mathrm{H}_{2} \mathrm{O}_{2} \rightarrow \mathrm{Cu}(\mathrm{II})+\mathrm{OH}^{*}+\mathrm{OH}^{-} \\
\mathrm{Fe}(\mathrm{II})+\mathrm{H}_{2} \mathrm{O}_{2} \rightarrow \mathrm{Fe}(\mathrm{III})+\mathrm{OH}^{*}+\mathrm{OH}^{-}
\end{gathered}
$$

The XRD analysis conducted for activated carbon saturated with $\mathrm{Cu}(\mathrm{II})$ and exposed to $\mathrm{H}_{2} \mathrm{O}_{2}$ (Fig. 1) points out to the presence of $\mathrm{Cu}(\mathrm{I})$, which confirms the proposed mechanism of formation of hydroxyl radicals.

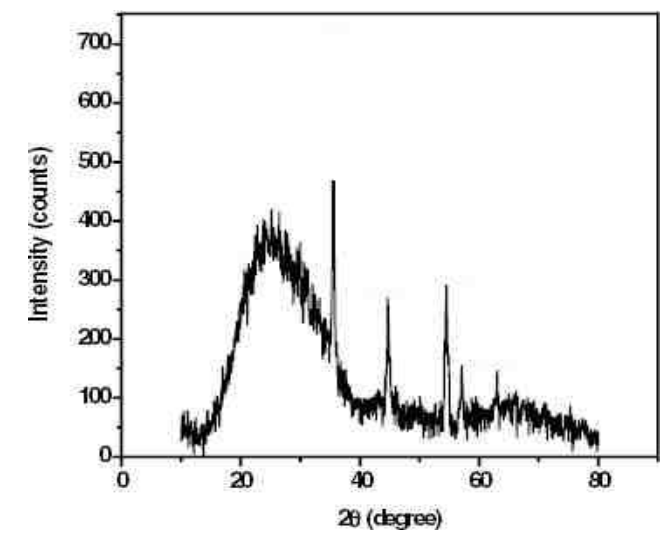

Fig. 1. An XRD analysis of activated carbon F-300 saturated with $\mathrm{Cu}$ (II) and exposed to $\mathrm{H}_{2} \mathrm{O}_{2}$

The reaction of both $\mathrm{Cu}(\mathrm{II})$ and $\mathrm{Fe}(\mathrm{II})$ ions with hydrogen peroxide resulted in the generation of hydroxyl radicals responsible for oxidation. The improvement in the regeneration efficiency was due to the presence of copper. The efficiency and effectiveness of oxidation of organic compounds were dependent on the amount of hydroxyl radicals and the time of their generation. In Fenton's reaction, the presence of $\mathrm{Fe}$ (II) ions caused immediate formation of radicals $\left(10^{6} \div 10^{9} \mathrm{M}^{-1} \mathrm{~s}^{-1}\right)$ [4], which is not always favourable because too high a concentration of radicals can lead to the deactivation of the reaction. As a two-stage process, the formation of hydroxyl radicals in the presence of $\mathrm{Cu}$ (II) is probably slower. Hydroxyl radicals are gradually introduced into the reaction environment, which contributes to higher efficiency of the oxidation of adsorbed phenol. However, the oxidizing agent introduced into the reaction system affects not only the adsorbed phenol; it oxidizes the surface of the activated carbon as well. This results in the regeneration of the activated carbon and, accordingly, an increase in its acidity at the surface. Higher concentrations of acidic surface groups favour the sorption of $\mathrm{Cu}(\mathrm{II})$ ions and the adsorbed metal ions favour the sorption of phenol.

The sorptive capacity of carbons after regeneration (Table 3) was lower than that of virgin carbon, F-300 (Table 2), which indicates that the oxidation at the stoichiometric ratio of the amount of the adsorbed organic substance to the oxidant was only partial. A possible reason for that is the polymerization of phenol adsorbed on activated carbon. The course of the oxidation reaction is then different from that when the process occurs in a solution. 
Another explanation of the partial oxidation of phenol can be the reaction of the oxidant with the carbon matrix, accompanied by a large loss of mass of the activated carbon. Also in this case, the presence of metals on the sorbent surface results in a greater loss of mass, which means that the activated carbon is also oxidized.

Completely different effects of regeneration were observed when nitric acid solution was applied as an oxidizing agent. In that case, the sorptive capacity of regenerated activated carbon with respect to phenol was $100 \div 80 \mathrm{mg} / \mathrm{g}$, which was considerably less than that obtained for virgin carbon, ie $180 \mathrm{mg} / \mathrm{g}$ (Table 3). The dramatic decrease in the sorptive capacity of activated carbon treated with nitric acid with respect to phenol can be explained by the considerable increase in the acidity of the surface and its simultaneous reduction (Table 1), which is accompanied by a significant loss of mass. This confirms the previous findings that excessive oxidation is not favourable for the sorption of phenol and regeneration of activated carbon by oxidation of the adsorbed substance. Thus, the procedure cannot be recommended as a regeneration method.

Table 3

Sorptive capacity of regenerated activated carbon, F-300, according to the regeneration conditions and the sequence of the substances sorbed

\begin{tabular}{|c|c|c|c|c|c|c|c|c|c|}
\hline & & & \multicolumn{7}{|c|}{ Sorptive capacity of regenerated } \\
activated carbons \\
[mg/g]
\end{tabular}




\section{Conclusions}

The results show that the oxidation of phenol adsorbed on the surface of activated carbon can be used for the disposal and regeneration of activated carbon. The process efficiency is dependent on the type of oxidant used and the presence of heavy metals. The oxidation of the adsorbed phenol with $1: 1 \mathrm{HNO}_{3}$ solution at its boiling point resulted in a considerable reduction and oxidation of the specific surface. The regeneration caused that the sorptive capacity of the activated carbon with respect to phenol was lower than that of virgin carbon. The chemical regeneration of activated carbons saturated with phenol using $\mathrm{H}_{2} \mathrm{O}_{2}$ and $\mathrm{Fe}^{2+} / \mathrm{H}_{2} \mathrm{O}_{2}$ led to the oxidation of the adsorbed organic substance, but the changes in the porous structure and surface acidity were smaller. As a consequence, the sorptive capacity of the regenerated carbons with respect to phenol was higher than that obtained after oxidation in the environment of the nitric acid solution.

The presence of $\mathrm{Cu}(\mathrm{II})$ or $\mathrm{Fe}(\mathrm{II})$ ions adsorbed on activated carbon caused a significant improvement in the regeneration efficiency and then the sorptive capacity of regenerated activated carbons. The results indicate that the adsorbed metals participated in the generation of hydroxyl radicals responsible for the oxidation of phenol. The presence of metals on the surface of the regenerated activated carbons caused donor-acceptor interactions between metal and electrons $\pi$ of the aromatic rings, which facilitated the sorption of phenol. The oxidation efficiency with respect to adsorbed phenol was higher in the presence of copper than in the presence of iron. It should also be mentioned that the oxidation of phenol was accompanied by the oxidation of activated carbon, which resulted in a considerable loss of the sorbent mass.

\section{Acknowledgements}

The authors acknowledge support from the Ministry of Science and Higher Education (project No. N N205 1993 33) and the Kielce University of Technology (statutory project No. 2.24/5.02).

In the academic year 2010/2011, Anna Picheta-Oleś, who is a PhD student at the Kielce University of Technology, has been awarded a grant co-financed by the EU European Social Fund within the Programme for the Development of the Educational Potential of the Kielce University of Technology: Education for success, Agreement No. UDA-POKL.04.01.01-00-175/08-02, Priority IV, Measure 4.1, Action 4.1.1.

The student is a holder of a grant co-financed by the EU European Social Fund within the above-mentioned project.

\section{References}

[1] Huang HH, Lu MC, Chen JN, Lee CT. Catalytic decomposition of hydrogen peroxide and 4-chlorophenol in the presence of modified activated carbons. Chemosphere. 2003;51:935-943.

[2] Luis A, Lombrañ JI, Varona F, Menéndez A. Kinetic study and hydrogen peroxide consumption of phenolic compounds oxidation by Fenton's reagent. Korean J Chem Eng. 2009;26(1):48-56.

[3] Vidic RD, Suidan MT, Sorial GA, Brenner RC. Effect of molecular oxygen on adsorptive capacity and extraction efficiency of granular activated carbon for three ortho-substituted phenols. J Hazard Mater. 1994;38:373-388.

[4] Rey A, Faraldos M, Casas JA, Zazo JA, Bahamonde A, Rodriguez JJ. Catalytic wet peroxide oxidation of phenol over Fe/AC catalysts: Influence of iron precursor and actvated carbon surface. Appl Catal B-Environ. 2009;86:69-77. 
[5] Richard S, Horng RS, Tseng I-Chin. Regeneration of granular activated carbon saturated with acetone and isopropyl alcohol via a recirculation process under $\mathrm{H}_{2} \mathrm{O}_{2} / \mathrm{UV}$ oxidation. J Hazard Mater. 2008;154:366-372. DOI: 10.1016/j.jhazmat.2007.10.033.

[6] Sunaric SM, Mitic SS, Miletic G.Z, Pavlovic AN, Naskovic-Djokic D. Determination of doxycycline in pharmaceuticals based on its degradation by $\mathrm{Cu}(\mathrm{II}) / \mathrm{H}_{2} \mathrm{O}_{2}$ reagent in aqueous solution. $\mathrm{J}$ Anal Chem. 2009;64(3):231-237.

[7] Tekin H, Bilkay O, Ataberk SS, Balta TH, Ceribasi H, Sanin D, Filiz B, Dilek FB, Yetis U. Use of Fenton oxidation to improve the biodegradability of a pharmaceutical wastewater. $J$ Hazard Mater. 2006;B136:258-265.

[8] Toledo LC, Silva ACB, Augusti R, Lago RM. Application of Fenton's reagent to regenerate activated carbon saturated with organochlorocompounds. Chemosphere. 2003;50:1049-1054.

[9] Bansal RCh, Goyal M. Activated Carbon Adsorption. Boca Raton-London-New York-Singapore: Taylor \& Francis Group; 2005.

[10] Biniak S, Pakuła M, Szymański S, Świątkowski A. Effect of activated carbon surface oxygen- and/or nitrogen containing groups on adsorption of copper(II) ions from aqueous solution. Langmuir. 1999; 15:6117-6122.

[11] Dąbek L. Regeneration of spent activated carbons. Monografie, Studia, Rozprawy M1. Kielce: Wydawnictwo Politechniki Świętokrzyskiej; 2007.

\title{
OCENA WPŁYWU OBECNOŚCI METALI CIĘŻKICH \\ ZAADSORBOWANYCH NA WĘGLU AKTYWNYM \\ NA SKUTECZNOŚĆ DEGRADACJI FENOLU WYBRANYMI CZYNNIKAMI UTLENIAJĄCYMI
}

\author{
Wydział Budownictwa i Inżynierii Środowiska, Politechnika Świętokrzyska, Kielce
}

\begin{abstract}
Abstrakt: Usuwanie zanieczyszczeń organicznych ze ścieków jest złożonym problemem wymagającym stosowania różnych metod. Coraz częściej rozważa się możliwość wykorzystania do tego celu procesu sorpcji i metod pogłębionego utleniania (AOPs), co jednocześnie skutkuje regeneracją węgla aktywnego. W prezentowanej pracy prowadzono badania wpływu zaadsorbowanych na węglu aktywnym jonów $\mathrm{Cu}$ (II) i $\mathrm{Fe}$ (II) na skuteczność utleniania fenolu z wykorzystaniem $\mathrm{H}_{2} \mathrm{O}_{2}$, reakcji Fentona $\mathrm{Fe}^{2+} / \mathrm{H}_{2} \mathrm{O}_{2}$ oraz roztworu $1: 1 \mathrm{HNO}_{3}$ w obecności mikrofal $2450 \mathrm{MHz}$, a tym samym wpływu na zdolność sorpcyjną zregenerowanych węgli aktywnych. Wykazano, że chemiczna regeneracja węgla aktywnego z wykorzystaniem metod AOP skutkuje częściowym utlenieniem zaadsorbowanej substancji organicznej. Obecność jonów Cu(II) lub Fe(II) zwiększa skuteczność regeneracji. Wykorzystanie kwasu azotowego do utleniania zaadsorbowanego fenolu skutkuje drastycznym obniżeniem zdolności sorpcyjnych węgla aktywnego względem tej substancji i wzrostem zdolności sorpcyjnych względem jonów metali. Niestety negatywnym skutkiem procesu utleniania zaadsorbowanego fenolu, niezależnie od zastosowanego czynnika utleniającego, jest znaczący ubytek masy węgla aktywnego.
\end{abstract}

Słowa kluczowe: węgiel aktywny, sorpcja, regeneracja, utlenianie, metale ciężkie 